\title{
The Eurasian Economic Union: the geopolitics of authoritarian cooperation
}

\section{Sean Roberts}

\begin{abstract}
Understanding cooperation among authoritarian regimes remains a puzzle for researchers; in particular, those working in post-Soviet Eurasia. Research suggests that autocrats are becoming increasingly coordinated in their efforts to thwart democracy, with authoritarian-led regional organizations offering an effective vehicle to extend autocrat time horizons. In contrast, older studies, including insights from failed regional integration among former Soviet states, suggest that the absence of democracy limits cooperation, although in both cases there is a lack of detail on the mechanisms enabling or constraining relations between autocrats. This article addresses this shortcoming by developing a theoretical framework based around autocrat survivability or "regime security" and applying it to the important case of the newly formed Eurasian Economic Union (EAEU), drawing on original interview data with experts and stake-holders in Belarus, Kazakhstan, and Russia. The argument forwarded in this article is that concerns over regime security create antagonistic cooperation drivers. In the case of the EAEU, regime security provides a strong explanation for the inability of member states to coordinate policy. The implication is that future studies should pay close attention to the way the material and ideational aspects of authoritarian rule combine to drive, but also limit relations between autocrats.
\end{abstract}

Key words: Eurasian; cooperation; authoritarianism; Russia; security

Sean P. Roberts, University of Portsmouth, UK.

\section{Acknowledgments}

The author would like to thank the Finnish Institute of International Affairs and the Finnish Ministry for Foreign Affairs for making this research possible. In particular, the author would like to thank Arkady Moshes; Katri Pynnöniemi and Anaïs Marin for their contribution to the initial research conducted in 2014. All views expressed in this article are those of the author. 


\section{Introduction}

Research on the international dimensions of authoritarian rule suggests that autocrats are becoming increasingly coordinated in their efforts to thwart democracy, and that authoritarian-led regional organisations offer an effective vehicle to bolster non-democracies and extend autocrat timehorizons (Ambrosio 2009; Bader et al. 2010; Borzel et al. 2013; Libman 2015; Silitski 2010; Tansey 2016; Von Soest 2015). With the fragile status of democracy in many parts of the world, authoritarian cooperation has the potential to alter the political balance and to create a zone of illiberal states united in mutually reinforcing institutions.

Indeed, authoritarian cooperation is not static, but appears increasingly ambitious, in particular in the post-Soviet space. The literature has already noted the expanding remit of the Russia-China led Shanghai Cooperation Organisation (SCO), which has grown to include election monitoring and formal cooperation with other regional organisations (Ambrosio 2009, 182). But of potentially greater significance is the creation of a qualitatively new kind of authoritarian integration project in the form of the Eurasian Economic Union (EAEU).

This important regional organisation was established in 2015 and represents an alternative to the EU, but in a de-politicised institutional framework, offering current and prospective members a path to economic modernisation without democratic conditionality. Hailed by its founders as a means to achieve deep integration in a short period of time and to change the geopolitical configuration of the continent (Putin 2011), the EAEU has already raised concerns in some quarters of a 'reSovietisation' of the region (FT 2012). With what we know about the geographical limits of democratic diffusion (Kopstein and Reilly 2000) and with the backdrop of the 2008 Global Financial Crisis and the EU's internal problems, the EAEU may well find opportunities to expand its influence. To an extent, this is already happening. The EAEU incorporated Kyrgyzstan and Armenia as new members in 2015 in regions (Central Asia and the South Caucasus) where the EU's influence is under pressure.

However, while recent studies suggest that authoritarian regimes are becoming increasingly integrated, older studies, including insights from failed integration among former Soviet states present a conflicting image of authoritarian cooperation, suggesting that the absence of democracy acts as a significant centrifugal force (Allison 2008; Bohr 2004; Collins 2009; Haas 1966). Rather than facilitate cooperation, similar authoritarian political systems act as a barrier, supported by the poor results of post-Soviet regional integration since 1991 (Kobrinskaya 2007; Olcott, Åslund and Garnett 1999; Vinokurov and Libman 2012).

In fact, the EAEU, despite its relative novelty, appears to reflect this puzzle, with scholars unsure if the EAEU is seeking EU-style 'deep integration' or something more modest and in line with the general experience of post-Soviet integration (Dragneva and Wolczuk 2012, 220). In short, there appear to be conflicting images of authoritarian cooperation - one where autocrats are increasingly coordinated and united in their dealings with each other, and one where authoritarian regimes are greatly restricted in their capacity for international cooperation. Clearly, these images are of great significance for both regional and international politics, in particular in the context of democratic roll-back in post-Soviet Eurasia and other regions. But, as discussed in this article, part of problem 
lies in the fragmented and implicit treatment of the dynamics of authoritarian cooperation in existing studies.

This article addresses this shortcoming by revisiting the extant regime studies and regionalism literature to elaborate a framework to explain authoritarian cooperation, based on the importance of autocrat survivability or 'regime security', in contrast to mainstream theories emphasising state survival and state security, and which includes both material and ideational components. The remainder of this article then applies this framework to the case of the EAEU, utilising primary and secondary sources as well as original qualitative data from fieldwork conducted in Belarus, Kazakhstan and Russia in 2014 and Russia in 2016. This fieldwork included semi-structured interviews with thirty stakeholders, policy makers and experts in these three founding member states, including representatives from foreign and economic ministries and the nascent Eurasian Economic Commission - the supranational component of the EAEU (Appendix 1), offering a unique opportunity to explore the dynamics of authoritarian cooperation from the perspective of those states involved.

This article proceeds as follows. The first two parts outline the puzzle of authoritarian cooperation and develop the regime security framework. The remainder of this article then applies this framework to consider the case of the EAEU, first in terms of regime security as a driver for cooperation and then as a brake, inhibiting cooperation. The final section considers the way regime security and regime identity combine to limit deeper cooperation, in particular sovereignty pooling. The argument forwarded in this article is that concerns over regime security create antagonistic drivers for cooperation. In the case of the EAEU, regime security offers some explanation for cooperation between member states, while providing a stronger explanation for their inability to coordinate policy. The implication is that future studies should pay close attention to the way the material and ideational aspects of authoritarian rule combine to drive, but also limit relations between autocrats.

\section{The puzzle of authoritarian cooperation}

Coinciding with the perceived retreat of global democracy, scholars have turned their attention to the international dimensions of authoritarian rule, including authoritarian cooperation, in an attempt to better understand this emerging trend. Although undertheorized (Von Soest 2015, 628) with research said to be in its early stages of development (Tansey 2016, 201), existing studies suggest that authoritarian regimes are becoming increasingly coordinated in pursuit of a common agenda that includes the establishment of regional orders and the replacement of democratic norms with their own non-democratic values (Ambrosio 24, 2009). Some scholars have even hypothesised an emerging 'authoritarian international', united in a common objective of thwarting unwelcome international influences, notably the spread of democracy (Silitski 2010, 341). Although evidence is far from conclusive, the appearance of relatively dynamic authoritarian-led regional organisations, such as the SCO and EAEU, supports the notion that authoritarian cooperation is evolving, if not deepening.

According to this literature, regional organisations potentially represent a significant 'next step' in authoritarian cooperation, offering an effective means to stabilise and bolster autocrats with the potential to create an expanding zone of illiberal coordination. Libman (2015), for example, 
theorises a number of regime-boosting functions performed by authoritarian-led regional organisations, including legitimacy provision, economic support, governance transfer, mutual learning and the socialisation/financial support of private business interests. Tansey $(2016,68)$ highlights the importance authoritarian sponsorship via regional organisations, including money and weapon transfers and diplomatic support. At the micro level, it has even been suggested that the freedom of movement associated with regional integration may help autocrats redirect opponents away from activism in their home country toward politically or economically motivated migration (Obydenkova and Libman 2015, 21).

Overall, this increasingly complex authoritarian cooperation has a 'common sense' logic. It has long been noted by first wave integration scholars that shared values and beliefs facilitate regional integration (Nye 1968, 423), while more recent literature has also indicated that autocrats prefer cooperating with other autocrats in 'similar systems' (Bader et al. 2010, 96). In the case of postSoviet Eurasia, there are no shortage of commonalities that may be expected to drive cooperation among authoritarian regimes, some of which are noted in existing studies (Lane 2015, 14; Libman and Vinokurov 2012,14). Beyond authoritarianism, these commonalities include similar economic systems (relatively high-levels of state intervention and a high importance of hydrocarbons), high levels of economic interdependence, similar security and modernisation concerns, but also a range of cultural, historical and linguistic features, (notably the prevalence of Russian language) that go some way to explaining the close alignment among certain post-Soviet states following the collapse of the USSR.

However, the relatively recent interest in the dynamics of authoritarian cooperation and its potential to re-define regions stands at odds with existing research detailing the problems of cooperation, including integration, in the post-Soviet space. While it is not inconceivable that autocrats in the region have gradually grown more united in their opposition to a single issue (e.g. the spread of democracy) or that some galvanising event has focused states on the need for deeper cooperation (e.g. the Global Financial Crisis), when viewed from the perspective of previous studies this apparent increase in authoritarian coordination is puzzling.

The literature detailing post-Soviet regionalism is illustrative of this point. Between 1991 and 2010, 36 regional organisations were established in the post-Soviet space making it one of the most active regions in the world in terms of integration (Keukeleire and Petrova 2016, 270). While the participating states were not always clear-cut autocracies, the turn-over of regional organisations combined with the prevalence of non-democratic regimes in the region points to a significant coordination problem. In fact, scholars have resorted to 'adjective regionalism' to capture this reality, characterising integration as 'ink-on-paper' (Vinokurov and Libman 2012, 53) 'stalled' (Collins 2009, 254) or 'virtual' (Allison 2008, 185), pointing to a circumstance where high-level statements of intent are rarely matched by corresponding levels of commitment.

At a generalised level, a number of explanations have been forwarded to explain these poor results, such as the fear of economic and military asymmetry that exits between Russia and all other postSoviet states (Libman and Vinokurov 2012, 192), elite preoccupation with defending sovereignty (Olcott, Åslund and Garnett 1999, 22-28) and a general predilection to ignore sovereignty pooling commitments and to by-pass the rules (Kobrinskaya 2007, 14-15). However, in many cases the 
prevalence of non-democratic regimes was also viewed as a significant barrier to effective cooperation (Allison 2008; Bohr 2004; Collins 2009), notably in the way that national interests are subordinated to the interests of the ruling group. This chimes with the work of early integration scholars, who noted the importance of democracy as a pre-requisite for successful integration, highlighting the difficulty of authoritarian regimes in meeting their integration commitments (Haas 1966, 106).

From this perspective, the puzzle of authoritarian cooperation is that similarity, in particular similar political systems, is theorised as both a push and pull factor in relations between autocrats. While these conflicting images of authoritarian cooperation are not necessarily mutually exclusive, the puzzle is magnified by the absence of a clear framework that can serve as an entry point to better identify the drivers behind these processes and how they work.

\section{The framework: Regime security as a key variable in authoritarian cooperation}

The approach taken in this article is to reconcile these competing images by revisiting the regime studies and regionalism literature in order to find common ground between regime type and cooperation drivers. As discussed below, the desire of autocrats to retain power makes concerns over regime security a key variable for understanding authoritarian cooperation - a point that is often implicit and fragmented in existing literature. Regime security is defined as 'the condition where governing elites are secure from violent challenges to their rule' (Jackson 2013, 162) and stands in contrast to mainstream theories that emphasise state security/survival as a foreign policy driver (see below). For the purposes of this article, cooperation occurs when actors adjust their behaviour, through a process of policy coordination, so that partners view them as facilitating the realization of their own objectives (Keohane 2005, 50-51).

Despite the recent focus on the democracy-thwarting potential of authoritarian cooperation, existing literature gives a strong hint that regime security is an underlying motivation. There is an acknowledgment, for example, that the ultimate goal of autocrats is to extend time horizons or to ensure what Ambrosio terms 'regime survivability' $(2009,19)$. As Von Soest notes; regimes collaborate when faced with an existential threat $(2015,624)$, and it is the threat to regime survival more than any other that drives authoritarian foreign policies, in particular in the post-Soviet space (White and Feklyunina 2014, 239). Overall, cooperation is seen as a logical security strategy in the sense that 'isolated regimes are vulnerable' and that authoritarian leaders who sit back and watch allies 'founder', magnify threats to their own rule (Whitehead 2014, 9).

As detailed in the case of the EAEU, authoritarian cooperation designed to bolster regime security does not necessarily take the form of collective security or defence organisations, although this sometimes is the case. We know from comparative experience that economic cooperation among autocrats often carries a distinct security aspect. The Gulf Cooperation Council (GCC), for example, was formed as a vehicle for economic and security cooperation in response to the dual threats of the USSR and Iran (Walt 1987, 270), but also internal dissent and internal pressures (Priess 1996). But, this is by no means an indication of 'authoritarian exceptionalism'. State security has long been theorised as a central foreign policy driver (Waltz 1979) and an important component of economic integration per se (Buzan 2003), including European economic integration (Moravcsik 1998, 5-6), although for authoritarian leaders, survival becomes a first-order interest to which all others are 
subordinate - a point supported in post-Soviet area studies literature (Allison 2004, 469; Collins 2009, 251; Miller and Toritsyn 2005, 332).

\section{Regime security as a brake on cooperation}

In sum, the hypothesis that regime security drives authoritarian cooperation is both testable and derived from existing literature and provides an entry point to better understand relations between authoritarian regimes. However, a corollary of this is that cooperation that is deemed to endanger regime security is likely to be avoided or curtailed by the autocrats in question. Again, existing regime studies and regionalism literature support this assertion, although again it is fragmented and often implicit.

For example, from what we know of the ability of intergovernmental organisations to promote democracy, there are obvious reasons why autocrats may be reluctant to deepen interdependence with other states through authoritarian-led equivalents. International organisations are seen to be effective democracy promoters because they provide increased leverage over the domestic affairs of member states, opening the way for targeted sanctions, if a member strays from the collective norms of that organisation. Sanctions such as de-legitimization through diplomatic pressure, economic sanctions and even the negative conditionality of expulsion from the organisation are powerful mechanisms to affect domestic political outcomes (Pevehouse 2002, 522). Some scholars have already asked if autocrats prefer weaker forms of cooperation (Von Soest 2015, 633) presumably in acknowledgement of this point.

As a result, and under certain circumstances, cooperation may enhance but also weaken regime security. Cooperation may gain autocrats powerful patrons able to provide security guarantees and bolster incumbents, vis-à-vis domestic and international opposition - as the regime studies literature suggests. But, cooperation may afford the same partner states an undesirable level of influence over domestic affairs, which may undermine key pillars of regime control and stability. Even without the threat of direct interference, cooperation commitments that involve sustained policy coordination may require significant changes to existing socio-economic relations within and between states, which may directly challenge the ruling group.

This point, on the delicate multi-balancing that autocrats must engage in is a little ambiguous in existing studies. Tansey, for example, mentions that for autocrats to stay in power, they must consider the balance of international pressure and support bearing on them, to maximise the latter and minimise the former (Tansey 2016, 4). But for any regime, the option of maximising international support, in particular through deeper forms of cooperation, must be weighed against domestic pressures. Close cooperation with other states may accrue direct material benefits for the ruling group, but unsettle the delicate balance among domestic constituencies.

This suggests the presence of tipping points, based around the balance between the internal and external aspects of regime security and which potentially limit the extent of authoritarian cooperation. This, in many ways, is unsurprising. Existing literature has long emphasised the way that foreign policy in democratic states, including the decision to cooperate with other states, is an outcome of bargaining between domestic groups and the economic costs and benefits they anticipate. Frameworks which combine domestic and international-level factors to explain foreign 
policy decisions, such as Putnam's dual-level game (Putnam 1988) or more sophisticated versions (Milner 1997) usefully capture the tension between domestic constituencies. The limited pluralism found in most authoritarian regimes reduces scope for bargaining, but concerns over regime security mean that autocrats must consider the domestic impact of their international cooperation.

\section{Regime security and regime identity}

This leads to the final point that the nature of regime security, depends in no small part on the characteristics of the regime in question. The authoritarian regime-type is hardly a residual category, and existing literature has long highlighted variations between authoritarian regimes, notably their differing institutions and locales of power (Huntington and Moore 1970; Geddes 2003). However, alongside these aforementioned material variations, careful attention needs to be given to ideational differences in order to avoid a narrow materialist ontology that may limit our understanding of authoritarian cooperation.

The literature on regional integration is quite illustrative. We know, for example, that the degree of commitment democratic states are able to make to each other depends on the compatibility of internal and external norms (Schimmelfennig and Sedelmeier 2005). The new regionalism literature has also highlighted the importance of identity for integration processes (Soderbaum and Shaw 2003), including 'Othering' (Nuemann 2003), while theorists have made an explicit connection between identities, institutions and democratic regime stability. Moravcsik, for example, notes that social actors provide support to government in return for institutions that accord with their 'identitybased preferences', institutions which then become 'legitimate' in their eyes (Moravcsik 1997, 525).

In terms of authoritarian regimes and in particular for the post-Soviet space, there have been attempts to highlight the role of identity in explaining foreign policy alignment (Ambrosio 2006), balancing behaviour (Gvalia et al. 2013) and the failure of Central Asian regionalism (Rosset and Svarin 2014). Elsewhere, literature has highlighted the role of national consciousness as an influence on integration (Hale 2008, 191) and the general ability of identity politics to 'trump' material factors when it comes to foreign policy (White and Feklyunina 2014, 238).

While the emerging literature on authoritarian cooperation has acknowledged that authoritarian regimes do not share a 'common identity' (Von Soest 2015, 626), there are grounds to go one step further and state that authoritarian regimes have unique identities, which are often cultivated as a component of the ruling group's legitimacy. This identity may take a number of forms, notably ethnonational, but it is none the less an important non-material aspect of regime security that incumbents must take into account when choosing international partners and in deciding the degree of commitment they make. There is some evidence that autocrats may forfeit a materially advantageous alignment with a foreign partner because of domestic opposition and the perceived threat to identity-based legitimacy (Ehteshami et al. 2013, 227), meaning autocrats must not only balance internal and external pressures but also material and ideational threats.

In this way, regime legitimacy is a function not only of regime performance (e.g. the ability to provide security to citizens, economic prosperity, etc. Miller 2006, 26-29.), but also the ability of incumbents to safeguard particular values, a way of life or set of relations between society and the 
state. As regime identity is defined by the ruling group, but also contested (other voices and identities exist, but are often repressed), any international cooperation that generates sustained contradictions to the regime's identity, risks encouraging and enabling challengers to 'outflank' incumbents with broad-based appeals for political change. This is particularly important in electoral authoritarian regimes. As most authoritarian regimes invest in a nominal 'democratic identity', elections are important events, but so too the ability of the ruling group to appeal to a core electorate and, if needed, mobilise pro-regime counter-protests. Both are a function of the material but also ideational capacity of incumbents.

In sum, the consideration of complex inter and intra regime balancing and ideational and material security provides a multi-level, multi-factorial framework to explore the dynamics of cooperation among autocrats. The next sections develop these ideas further through and examination of the EAEU, where evidence suggests that concerns over regime security do indeed create antagonistic drivers, facilitating but also inhibiting policy coordination.

\section{The case of Eurasian Economic integration}

The EAEU was formally signed into existence by the leaders of Belarus, Kazakhstan and Russia in January 2015 and joined shortly afterwards by Armenia (January 2015) and Kyrgyzstan (August 2015). It builds on an older idea of creating a customs union among newly independent states (Vinokurov 2007, 26) that found expression in the CIS Customs Union (1993), the Eurasian Economic Community (2000), Eurasian Customs Union (2010) and Single Economic Space (2012). Despite a bright start that saw trade volumes between Custom Union members increase in 2011/2012, the combination of sanctions and counter sanctions surrounding the ongoing Ukraine crisis and drop in oil prices has seen a consistent decrease in mutual trade, 2013-2016. Total exports (millions, USD) by EAEU member states to EAEU partners declined from a high of 67,856 in 2012 to 42,536 in 2016 (Eurasian Commission 2017).

In terms of suitability, the EAEU has high value as a case study of authoritarian cooperation. First, the EAEU is a good example of an authoritarian-led regional organisation. The EAEU founding members (Belarus, Kazakhstan and Russia) are clear non-democracies ('not free') with little to suggest they are marginal cases (Freedom House 2016) - despite attempts by ruling groups in each to sustain a façade of democracy. Second, the fact that the EAEU is an economic and not a security organisation provides an ideal opportunity to test the claim that regime security drives cooperation between autocratic states. Finally, the EAEU is an important case because of its implications for the region, but also the way it continues to draw divergent accounts from the literature, in particular if the EAEU is seeking EU-style deep integration or something more modest (Dragneva and Wolczuk 2012). As such, this article is able to contribute to this debate by exploring EAEU drivers and their strength and direction.

The following discussion draws on primary and secondary sources, as well as in-depth interviews conducted in 2014 just before the official unveiling of the EAEU, with follow up interviews conducted in 2016 (Appendix 1). Each interview focused on the motivations and perspectives of integration as seen by experts and stake-holders in each state. Overall, the choice of interviews is well-suited for this research, offering insider-views from the three founding member states and a unique opportunity to explore the dynamics of authoritarian cooperation from the perspective of 
those states involved. For ethical reasons interviewees are anonymised and cited by country (Belarus, Kazakhstan and Russia) or institutions (Eurasian Economic Commission) only.

\section{Regime security as a driver for cooperation?}

From the outset, the appearance and development of the EAEU has been accompanied by an obvious economic logic, meaning that, in the official discourse, economic rather than security factors present themselves as 'first order' drivers. With the inclusion of Armenia and Kyrgyzstan in 2015, the EAEU comprises a huge market of over 170 million people with a combined GDP of more than 2 trillion USD, creating substantial opportunities for domestic producers and for attracting foreign investment. With an explicit aim of realising the four economic freedoms and of coordinating economic policy among member states, the EAEU offers a long list of advantages for member states.

For Belarus and Kazakhstan, unfettered access to the huge Russian market offers immediate benefits, not least the opportunity to modernise their respective economies, without the risk of full exposure to the globalised economy. Companies in Belarus and Kazakhstan have the opportunity to become part of the Russian production chain and to benefit from Russian investment, as well as external investment from non-member states wishing to access the common market. For Russia, improved access to markets in Belarus and Kazakhstan (nine million and 17 million people respectively) is not insignificant, in particular for key manufacturing sectors, such as the automotive industry. Business also has the opportunity to relocate to member states to take advantage of differing tax regimes, if and when issues with residency are resolved.

In addition, and at a macro level, there is also an underlying assumption in each member state that the global economy is 'evolving in the direction of regional economic blocks and alliances' and that the next stage of development will likely see the creation of transregional alliances, like the Transatlantic Trade and Investment Partnership agreement (T-IPP) (Interview, Russia, 2014). As such, there is a consensus that the Eurasian region risks being left behind, if it continues to hesitate with its own integration projects. In fact, it is here at the macro level that we also find evidence that integration has a more tangible regime security component alongside the obvious economic drivers.

The first indication that the EAEU is a reaction to a perceived threat to regime security is seen in the form of the ongoing effects of the 2008 Global Financial Crisis. These effects were quick to materialise in the region, seen in Russia's economic slump in 2009 and the financial crisis in Belarus in 2011, but also in the longer-term drop in the price of oil - a key cog in the political economy of post-Soviet authoritarianism. Falling demand for oil without a corresponding drop in production has seen oil prices decline by two thirds in the period 2008-2016, affecting Russia and Kazakhstan as major oil exporters but also Belarus, whose economy derives significant revenue from refining oil. The removal of tariffs and a commitment to create common access to pipeline infrastructure are part of an attempt to mitigate the reliance that each member state has on international commodity markets.

In addition, the economic slowdown that followed the 2008 Financial Crisis refocused regional leaders on the need to diversify their economies (Putin 2014a), with the removal of tariffs seen as an important step in stimulating other sectors of the economy and raising competitiveness in a region 
that lags behind others on most comparative measures. As such, the on-going effects of the 2008 financial crisis have led to an understanding that cooperation is essential or as one interviewee remarked: 'keeping together gives us added value' (Interview, Russia, 2014). In this sense, the EAEU serves as a vehicle for economic modernisation among states with similar levels of development.

In fact, this idea of economic vulnerability ties into the second threat to regime security that underpins Eurasian economic integration - the growing influence of the 'democratic' European Union (EU), but also 'authoritarian' China in the region. In many ways, this is unsurprising, as customs unions are designed to create but also divert trade (Mattli 1999, 11) and without trade diversion the presence of two huge economies on the western and eastern flanks poses a longerterm threat to the security of ruling groups in the region. Even though the economies of Belarus, Kazakhstan and Russia benefited from rising oil prices and a general economic upturn, 2000-2008, the expansion of EU and Chinese economies is hard to ignore. In the period 1991 up the creation of the EAEU in 2015, the EU's GDP grew from 7.8 to 16.3 trillion USD, while China's GDP increased from 3.8 billion USD to 11 trillion USD (World Bank EU; World Bank China 2017) - in both cases dwarfing the 2 trillion USD combined GDP EAEU member states.

For Belarus and Russia, the implications of Chinese investment and the growing trade-imbalance have yet to receive public attention, but it is Kazakhstan where a growing nationalist sentiment combines with a fear of China (Interview, Kazakhstan, 2014) and where the nature of KazakhstanChina relations are openly discussed in public. Here, the economic threat posed by China is seen in terms of cheap goods undercutting domestic producers, but also the unease felt in some quarters at growing Chinese influence in the country. As such, the EAEU is viewed as a necessary step to shield Kazakhstan from China's presence in the region.

Like China, the EU is also viewed as an economic threat, but here the boundary between economics and politics becomes blurred. For some, the new generation of Association Agreements drafted by the EU in 2009 served as a direct stimulus for Eurasian economic integration, as Russia along with other states in the region were forced to respond (Adomeit 2012). This corresponds to a general understanding in Moscow at least, that if Russia is not pushing a cooperation agenda in the region, then others will fill the vacuum: 'if Russia is not actively promoting this concept [integration], then neighbouring countries will get engaged in other integration projects' (Interview, Russia, 2014).

More importantly, there is also a belief among member states that the EU is heavily politicised, meaning that political expansion accompanies economic expansion - something viewed as intrinsically threatening. This links to the third regime security threat that the EAEU is designed to counter - externally provoked regime change or a Ukrainian-style 'Maidan' uprising, spreading as a contagion to neighbouring states, either through a spontaneous demonstration effect or directed by hostile third parties.

In both Russia and Belarus, notions of a fifth column are frequently articulated by the regime. In Russia, this is a fully fledged public discourse focused on the entire spectrum of regime opponents (Lipman 2015), while in Belarus the Polish minority has been targeted, in particular following the introduction of a Polish Ethnicity Card for citizens of the former USSR in 2007 (BTI 2014, 5). Kazakhstan also has significant issues with domestic opposition, at times drawing direct criticism 
from the EU (Savchenko 2015) and exacerbated by ongoing concerns surrounding political stability and leadership succession. The EAEU provides an opportunity to stabilise regimes through gradual economic development, as well as offering the prospect of collective action and external assistance from partners, if and when needed.

In this sense, there is some evidence that the role of the EAEU is to complement other securityfocused integration projects to resist the spread of colour revolution. In June 2012, Belarus leader Aleksandr Lukashenko met with Vladimir Putin to discuss the threat of sanctions and western sponsored regime change (Lukashenko 2012). Belarus, like Russia, is no stranger to EU economic sanctions. Following a brief period of détente with the West that saw Belarus sign up to the EU's Eastern Partnership in 2009, the EU imposed rolling sanctions in the wake of Lukashenko's December 2010 presidential election victory and an accompanying crackdown on regime opposition figures (Benzow 2011). The EAEU, alongside other structures, such as the Belarus-Russia Union State Treaty and the Shanghai Cooperation Organization provides an extra layer of support, including financial assistance, in circumstances when other sources of credit may become unavailable. In this regard, the EAEU is an important source of regime credit, acting through the financial mechanisms of the Eurasian Development Bank (EDB) and the Eurasian Stabilisation and Development Fund (ESDF). Since its creation in 2006, the EDB has invested around USD 4.85 billion in the region, while the ESDF, with capital of USD 8.5 billion, acts a regional IMF and a 'lender of last resort' (Vinokurov 2017, 58)

In addition, membership of the EAEU increases the prospects of direct support from Russia, both in terms of hard security guarantees but also direct economic support. Again, Belarus is illustrative of the economic benefit of closely aligning with Russia, not only through Moscow-approved bail-outs from the EDB in 2011, but also energy subsidies. Following a deal with Russia in 2014, Belarus pays no export duties on the oil it imports from Russia, refines and then sells on international markets (Interfax 2014) and overall it is estimated that Russian subsidies account for up to 20 per cent of Belarus's GDP, with half of all that country's exports going to Russia (Bentzen and Dietrich 2016). As one interviewee noted: 'Eurasian integration carries with it opportunities for us to keep on getting energy subsidies and rebates from Russia' (Interview, Belarus, 2014). This tallies with other studies of the EAEU that emphasise the importance of 'extractive relations' and the ability of ruling elites to continue to concentrate power and resources in their own hands (Ter-Matevosyan et al. 2017, 350).

\section{Regime security as a brake on cooperation?}

In the case of the EAEU there is no shortage of evidence of coordination problems between members-states, although these problems are in some ways exacerbated by international conditions. This is particularly evident in terms of foreign policy coordination against the backdrop of the Ukraine crisis and Russia's unilateral counter sanctions introduced in August 2014, which have proved a point of contention for both Belarus and Kazakhstan. In fact, the unwillingness of other EAEU member states to support Russian sanctions against Ukraine in itself shows the very real limits of authoritarian cooperation.

Elsewhere, the relatively high-number of coordination problems seen in the period 2015-2016 do not necessarily reflect deep-seated regime security issues, but general problems of trust-building 
familiar to most regional integration projects. In particular, the use of non-tariff barriers remains a problem, with each member state accusing partners of selectively applying them to protect domestic producers from competition.

For just one member state - Kazakhstan - the period 2015-2016 witnessed numerous trade disruptions with EAEU partners. In 2015 and 2016, Kazakhstan temporarily banned Russian food imports, citing health concerns and the need to protect consumers from poor quality products (Mgov.Kz 2016). In March 2015, Kazakhstan imposed a 45-day ban on Russian oil imports to protect domestic producers and in May 2015 the government approved new standards limiting the import of Russian and Belarussian vehicles (Rodeheffer 2015). This comes against a backdrop of currency devaluation and persistent accusations that member states are trying to boost the competitiveness of domestic producers.

In most cases, the numerous disputes among EAEU members in the period, 2015-2017, and following the official unveiling of the EAEU, reflect the weakness of institutions and by extension the Union's enforcement mechanisms. The supranational component of the EAEU - the Eurasian Economic Commission - has little power to influence domestic institutions, beyond urging compliance with regulations. In 2017, for example, the Commission acknowledged its inability to intervene in the so-called 'meat war' between Belarus and Russia and to force the Russian food inspection agency to remove punitive measure on Belarussian meat (Wolczuk and Dragneva 2017, 14). Likewise, the judicial body of the Union - the EAEU court - was deemed an ineffective mechanism for settling disputes by legal experts even before the EAEU came online in 2015 (Checkalov 2014, 12). Unsurprisingly, the Supreme Council, which consists of each head of state, is the highest body of the EAEU, meaning member state leaders retain high-levels of 'manual control' over the integration process as a whole (Roberts and Moshes 2016: 9).

At a deeper level, the choice of weak institutions and the selective enforcement of integration commitments reflect the fact the problematic relationship between regime security and policy coordination. For example, while the problem of non-tariff barriers is not unique to the post-Soviet space or other regional integration projects, there are deeper fears among EAEU member states that too much integration will mobilise domestic opposition and increase the political and economic leverage of partner states to an unacceptable level. This is particularly so for Russia's smaller partner states, where leaders understand the advantages of close cooperation with their larger neighbour, but also the risks involved.

Every post-Soviet state has economic relations with Russia and so some degree of interdependence, typically asymmetrical. The economies of Belarus and Kazakhstan and new EAEU members Armenia and Kyrgyzstan are reliant on Russian energy and energy providers in various forms, including the supply of oil and gas, transit of oil and gas, but also the operation of electricity and nuclear power sectors. In addition, most states in the region rely on access to the Russian market, not least in the form of worker remittances sent back from Russia. But for both Belarus and Kazakhstan, there are specific regime security issues at stake.

For Belarus, relations with Russia continue to operate on two levels. At an official level, Belarus and Russia are the closest-aligned states in the post-Soviet space; an alignment underpinned by the 1999 bilateral Union State Treaty and joint membership of a host of multilateral regional 
organisations. However, both states have a long history of coordination problems, including numerous oil and gas pricing conflicts and a host of other disagreements both before and after the official unveiling of the EAEU in 2015. In 2016, Moscow and Minsk clashed over plans to build a Russian airbase in Belarus and over the latter's introduction of border regulations affecting Russians travelling from the Kaliningrad enclave. Although Vladimir Putin identified Belarus as Russia's closest 'strategic partner' during a meeting with the Belarus President in July 2015 (Kremlin 2015) at an unofficial level, Aleksandr Lukashenko is viewed by Russia as a 'situational partner' - unreliable and willing to support Russian initiatives but only if the price is right.

However, the ability of the Lukashenko regime to extract concessions from Russia is tempered by the fact that the regime's existing limited leverage will diminish, if the Belarus economy is liberalised, as envisaged under the aegis of the EAEU. There is an acknowledgment within Belarus that reform is dangerous, not least because Russia is best placed to take advantage. Russia has greater bureaucratic resources and expertise than any other member state, which can be used to lobby and determine the path of integration. Moreover, it is Russian companies and Russian capital that are best poised to take advantage of new openings in neighbouring markets if and when liberalising reforms happen.

In terms of regime security, there is a fear that Russian criminal organisations or the Russian state may use economic reforms in Belarus to take a controlling stake in key industries, possibly through manipulating shareholders (Interview, Belarus, 2014) and from this position attempt to remove Lukashenko and replace him with a more malleable partner. Lukashenko himself has repeatedly claimed that Russia is seeking to undermine him, even going so far as to identify Russia as an existential threat to Belarus, alongside NATO (Moscow Times 2014). Following yet another gas pricing dispute in May 2016, Russian experts did not rule out a Moscow-backed attempt to remove Lukashenko in the near future (Hodasevich 2016a).

In comparison to Belarus, Kazakhstan's economic reliance on Russia is significantly less, but as interviewees noted, similar concerns exist that liberalising reforms will see Russian companies over-run domestic competition (Interview, Kazakhstan 2014). Moreover, Russia's increasing unpredictability as a partner is also creating concerns. In economic terms, Moscow's unilateral decision to impose counter-sanctions in 2014 dismayed many within Kazakhstan, as well as figures within the Eurasian Economic Commission (Interview, Eurasian Commission, 2016). In foreign policy terms, there is concern that Russia is pulling Kazakhstan into an isolationist project, leading some to question the motivations behind Russia's integration drive. As such, Russia's motives are increasingly viewed as geopolitical, in sharp contrast to Astana's stringent desire for a 'depoliticised economic-only project' (Interview, Kazakhstan 2014).

However, a qualitatively different issue for Kazakhstan is Russia's unpredictable use of force. The annexation of Crimea in 2014 and subsequent emergence of Putin's 'Crimea Doctrine' (Putin 2014b) and the readiness to intervene beyond the territory of the Russian Federation to defend ethnic Russians is a significant development. The combination of a large ethnic Russian population in the north of Kazakhstan and uncertainty concerning the post-Nazarbaev power succession opens up the possibility of Russian intervention in the future. While rarely mentioned in high-level statements within Kazakhstan, this hypothetical situation is acknowledged in Russian circles as a 
likely source of consternation in Kazakhstan, as well as other neighbouring states (interview, Russia, 2014). For some, there is little doubt that any political instability in Kazakhstan that threatens Moscow's interests will be met with military intervention: 'Russia will use force in Kazakhstan as a last resort to restore order' (Interview, Russia, 2016).

In addition, for both Belarus and Kazakhstan, there are clear indications that integration must be balanced with external security concerns but also internal tensions. In Belarus, attempts by the government to enforce EAEU regulations that small traders selling imported goods provide details of their origin have already resulted in protests. The so-called edict 222 came into force in January 2016 and resulted in several localised demonstrations in February and March 2016, with protestors and the opposition United Civic Party demanding the government's dismissal. Although relatively small in size (they numbered several hundred), this law may affect up to 120,000 small businesses (Marples 2016), but more importantly these protests were explicitly anti-Eurasian Union in nature (Hodasevich 2016b) and provide an early indication of the problems of enforcing integration commitments.

In Kazakhstan, moves to amend a law allowing foreign citizens to own land sparked widespread protests in April 2016, with tens of thousands taking to the streets. Eventually, Kazakhstan's leadership was forced to introduce a moratorium in August 2016 (RIA Novosti 2016). This comes against a backdrop of persistent negative media commentary on the EAEU within Kazakhstan (Likhachev 2015) and a growing dissatisfaction among business elites in the country at the poor results of integration to date. Throughout 2015 the government came under sustained (and successful) pressure from domestic producers to limit Russian imports. The pro-business 'loyal' opposition party, Ak Zhol, which supports protectionism, has repeatedly cautioned against Kazakhstan's involvement in the EAEU and any temptation to sacrifice the nation's sovereignty and independence.

\section{Regime identity and Eurasian economic integration}

What the cases of Belarus and Kazakhstan show is the delicate balance between the costs and benefits of policy coordination in political systems that lack the institutional means to absorb and accommodate popular dissatisfaction. In line with the regime security framework, both cases also reveal the ideational challenges that authoritarian cooperation poses, in particular sustained policy coordination and sovereignty pooling, when the adjustments needed to meet commitments to partner states threatens to undermine the regime identity that ruling groups have cultivated over a long period of rule.

In the case of the post-Soviet space, the break-up of the Soviet Union initiated a process of nation building in newly independent states, a process in which ruling groups became embedded first as initiators and then as defenders of an emerging national identity (Fawn 2004, 20). As such, for many post-Soviet states, regime identity is closely entwined with national identity, and with one or two notable exceptions (Belarus) this identity is based around ethnicity. In these terms, the resilience of many authoritarian regimes in the region is based on the (continuing) support of a core ethnic group which confers additional legitimacy on rulers, who promote themselves as 'defenders' of particularistic group interests. 
One exception is Belarus. Unlike most post-Soviet states, Belarusian national identity is weakly developed, although both Russia and Europe are often cast as significant 'Others' (White and Feklyunina 2014, 163, 165) with the regime shifting the state's official discourse between the two. In the place of nationalism, long-standing leader Aleksandr Lukashenko has built regime identity around a commitment to a socially oriented state, that sees relatively high levels of social welfare (albeit low quality) compared to Russia and Kazakhstan (Cook 2007) and relatively high levels of state ownership in the economy.

For Belarus, and for Lukashenko in particular, any economic reform must be gradual in order to preserve the regime's material control over the state, but also the regime's credentials as a defender of a particular way of life that has changed little since 1991. In order for Lukashenko to retain power, he must careful coordinate his policies in accordance with the preferences of his core electorate and supress market forces. As Zlotnikov notes, it would be difficult for Lukashenko to change his negative attitude toward the private sector because it would go against his own convictions, but also that of his electoral base (Zlotnikov 2004, 138).

However, this places Belarus in a paradoxical situation in the context of EAEU and the requirements of sustained policy coordination and economic integration. There is an open acknowledgement within the country and within the other EAEU member states that the Belarus economy lags in terms of levels of economic liberalisation. In 2011, following the Belarus financial crisis, loans from the EDB were conditioned on economic reform, including privatisation, but so far the Belarus leadership has continued to stall. The government's social and economic plan for the period 2016-2020 promises to 'modernise property relations' (Belarus 2016), but is at odds with other high-level statements on economic development. Lukashenko's address to the People's Assembly in July 2016 ruled out any deviation from the established 'gradualist' approach to modernisation (Lukashenko 2016). Within Belarus there is an opinion that the country will never meet all its integration commitments: 'Belarus will never adopt the economic rules and the principles of liberalism which prevail in Russia’ (Interview Belarus 2014).

In Kazakhstan, under the long-standing leadership of Nursultan Nazarbaev, the regime has built an identity around the values of sovereignty and political and economic independence, but underpinned by support for ethnic Kazakh nationalism. So, while Nazarbaev has been a consistent champion of Eurasian integration as a necessary tool to modernise the country, the regime's ethnonationalism implies a circumscribed limit to the extent of Kazakhstan's relations with Russia. Among the more controversial moves of the regime has made in recent years include a program for increasing the number of Kazakh-speakers in the country to 95 per cent by 2025 as well as a plan to 'modernise' the Kazakh alphabet by abandoning the existing Cyrillic in favour of a Latin script (Roberts and Moshes 2016, 13). In addition, there are indications that identity is hindering foreign policy coordination with Moscow and contributing to 'civilizational conflicts', as the regime gravitates toward ethnically similar Turkey and Azerbaijan (Galstyan 2017).

The problem for the ruling group in Kazakhstan is that Eurasian integration is increasingly challenging the regime's identity as a defender of the key values of sovereignty and independence as well as the interests of ethnic Kazakhs. While the focus of land reform protests in April 2016 carried a distinct anti-Chinese character (Solov'eva 2016), there exists a significant anti-Russian 
sentiment among Kazakh nationalists (Interview, Kazakhstan, 2014). This sentiment could create problems for the regime, if integration is perceived to disproportionally benefit Russia - as indeed the current media discourse within the country attests. Available opinion-poll data from 2014 just prior to the formation of the EAEU showed that ethnic Kazakhs (13.1 per cent) were almost three times more likely to oppose integration than ethnic Russians (4.9 per cent) living in Kazakhstan (KISI 2014, 47). In terms of regime security, failure to protect the right flank and to defend the values of sovereignty and the interests of ethnic Kazakhs, opens opportunities for challengers to appropriate the ideological space vacated by the regime as defenders of the nation's key constituencies and values.

\section{Conclusions}

This article contributes to the emerging literature on the international dimensions of authoritarian rule, but also the nascent Eurasian Economic Union (EAEU). The argument forwarded in this article is that concerns over regime security create antagonistic cooperation drivers. In the case of the EAEU, regime security offers some explanation for cooperation between member states, while providing a stronger explanation for their inability to coordinate policy. Rather than united in the perception of a common threat, EAEU member states are busy balancing multiple challenges to regime security, including those resulting from cooperation with their authoritarian partners. At the same time, rather than offer a problem free route to 'regime upgrading' or modernisation, ambitious cooperation projects, notably those involving economic integration, appear to contain tipping points and diminishing regime security returns. Despite the appearance of the ambitious EAEU, this article confirms the older regionalism literature that highlighted the poor results of post-Soviet integration since 1991.

In terms of better understanding the dynamics of authoritarian cooperation, there are a number of avenues that present themselves. The first is the difficult task of specifying tipping points in authoritarian cooperation. A second, related question is the compatibility of authoritarianism with any form of economic integration involving liberalising reforms. There is an argument that economic liberalism helps produce democracy by separating economic and political power (Ulfelder 2008, 274). Economic integration is also assumed to go 'hand in hand with the development of a democratic identity' (van der Vleuten and Hoffmann 2010, 739). From these perspectives, it is questionable if anything but token economic integration is compatible with authoritarian resilience.

A third and potentially more intriguing research avenue relates to authoritarian strategies for balancing internal and external pressures within regional organisations. This may involve a closer consideration of the malleability of regime identity in the hands of long-serving autocrats and the possibility that regimes may develop 'multiple' identities to ease integration concerns. Crossregional research would be best suited for observing the range of strategies designed to limit the impact of integration commitments while still extracting benefits. As in the case of the EAEU, this may include the use of non-tariff barriers, the creation of weak supra-national institutions, and general 'feet-dragging'. Another feature of the EAEU is the prevalence of individual state opt-outs and multi-speed integration that typically involve concessions in certain areas (e.g. regarding the Union's expansion) in order to buy time in others. In addition, the whole issue of multi-vectored 
foreign policies and an emerging discourse surrounding 'big Eurasia', including open regionalism, in particular in Belarus and Kazakhstan, suggest a mild attempt or strategy of 'soft balancing' Russia. Examining these strategies and others in the context of regional integration, both in and beyond the post-Soviet space, would serve to deepen our understanding of the dynamics of authoritarian cooperation.

\section{References}

Adomeit, Hannes. 2012. "Putin's Eurasian Union: Russia's Integration Project and Polices on PostSoviet Space." Neighborhood Policy Paper. Zurich: Center for International and European Studies.

Allison, Roy. 2004. "Regionalism, Regional Structures, and Security Management in Central Asia." International Affairs 80: 463-483.

Allison, Roy. 2008. 'Virtual Regionalism, Regional Structures and Regime Security in Central Asia’. Central Asian Survey 27: 185-202.

Ambrosio, Thomas. 2006. "The Non-material Cost of Bandwagoning: The Yugoslav Crisis and the Transformation of Russian Security Policy.” Contemporary Security Policy 27: 258-281.

Ambrosio, Thomas. 2009. Authoritarian Backlash: Russian Resistance to Democratization in the former Soviet Union. Ashgate, UK: Farnham.

Bader, Julia, Jörn Grävingholt, and Antje Kästner. 2010. "Would Autocracies promote Autocracy? A Political Economy Perspective on Regime-type Export in Regional Neighbourhoods." Contemporary Politics, 16: 81-100.

Belarus. 2016. "Proekt programmy social'no-ekonomicheskogo razvitiya Respubliki Belarus' na 2016-2020 gody (The socio-economic development programme of the Republic of Belarus, 20162020).” Accessed Jul. 2, 2017. http://www.president.gov.by/ru/sobranie/

Benzow, Gregg. 2011. "EU Imposes Sanctions against Belarus.” DW News. Accessed Jul. 2, 2017. http://www.dw.com/en/eu-imposes-sanctions-against-belarus/a-14807433

Bentzen, Naja, and Christian Dietrich. 2016. "Belarus: A Repressed Economy.” At a Glance, European Parliament. Accessed Jul. 2, 2017.

http://www.europarl.europa.eu/thinktank/en/search.html?keywords=001345

Bohr, Annette. 2004. "Regionalism in Central Asia: new geopolitics, old regional order. International Affairs." 80: 485-502.

Börzel, Tanja, and Mathis Lohaus. 2013. "Governance Transfer by Regional Organizations: Following a Global Script?” SFB Governance Working Paper Series 43. Accessed Jul. 2, 2017. http://edoc.vifapol.de/opus/volltexte/2015/5726/

BTI. 2014. BTI Belarus Country Report. Accessed Jul. 2, 2017. http://www.btiproject.org/fileadmin/files/BTI/Downloads/Reports/2014/pdf/BTI_2014_Belarus.pdf 
Buzan, Barry. 2003. "Regional Security Complex Theory in the Post-Cold War World." In Theories of New Regionalism, edited by F. Soderbaum and T. Shaw, 140-159. New York: Palgrave Macmillan.

Checkalov, D. 2014. 'Poryadok Razresheniya Sporov v Evraziiskom Ekonomicheskom Soyuze', Integrites Law Firm Kazakhstan. Accessed November 2, 2017.

http://www.integrites.com/ru/publication/792

Collins, Kathleen. 2009. "Economic and Security Regionalism among Patrimonial Authoritarian Regimes: The Case of Central Asia.” Europe-Asia Studies 61: 249-281.

Cook, Linda. 2007. Postcommunist Welfare States: Reform Politics in Russia and Eastern Europe. Ithaca, NY: Cornell University Press.

Ehteshami, Anoushiravan, Raymond Hinnebusch, Heidi Huuhtanen, Paola Raunio, Maaike Warnaar, and Tina Zintl. 2013. "Authoritarian Linkage and international Linkages in Iran and Syria.” In Middle East Authoritarianisms, edited by S. Heydemann and R. Leenders, 222-244. Stanford: Stanford University Press.

Dragneva, Rilka, and Kataryna Wolczuk. 2012. "Commitment, Asymmetry, and Flexibility: Making Sense of Eurasian Economic Integration.” In Eurasian Economic Integration: Law, Policy, and Politics, edited by R. Dragneva and K. Wolczuk, 204-221. Cheltenham, UK: Edward Elgar.

Eurasian Commission. 2017. "Vneshnyaya i vzaimnaya torgovlya tovarami Evraziiskogo ekonomicheskogo soyuza (External and mutual trade in goods by the EAEU)." Accessed Jul. 2, 2017.

http://eec.eaeunion.org/ru/act/integr_i_makroec/dep_stat/tradestat/time_series/Pages/default.aspx

Fawn, Rick. 2004. "Ideology and National Identity in Post-Communist Foreign Polices." In Ideology and National Identity in Post-Communist Foreign Polices, edited by R. Fawn, 1-42. London: Frank Cass.

Freedom House. 2016. “Eurasia.” Accessed Jul. 2, 2017. https://freedomhouse.org/regions/eurasia

Financial Times. 2012. "Clinton vows to thwart new Soviet Union." The Financial Times. Accessed Jul. 2, 2017. https://www.ft.com/content/a5b15b14-3fcf-11e2-9f71-00144feabdc0

Galstyan, A. 2017. 'Is the Eurasian Economic Union Slowly Coming Apart?' The National Interest. Accessed November 2, 2017. http://nationalinterest.org/feature/the-eurasian-economic-unionslowing-coming-apart-19947

Geddes, Barbara. 2003. Paradigms and Sand Castles: Theory Building and Research Design in Comparative Politics. Ann Arbor, MI: University of Michigan Press.

Gvalia, Giorgi, David Siroky, Bidzina Lebanidze, and Zurab Iashvili. 2013. "Thinking outside the bloc: explaining the foreign policies of small states.” Security Studies 22: 98-131.

Hale, Henry. 2008. The Foundation of Ethnic Politics: Separatism of States and Nations in Eurasia and the World. Cambridge, UK: Cambridge University Press. 
Haas, Ernst. 1966. International Political Communities. New York: Anchor Books.

Hodasevich, Anton. 2016a. "Lukashenko davit na Moskvu (Lukashenko pressures Moscow)." Nevazimaya gazeta. Accessed Jul. 2, 2017. http://www.ng.ru/cis/2016-05-16/6_lukashenko.html

Hodasevich, Anton. 2016b. "Biznes obeshchaet Lukashenko bol'shie problemy: Predprinimateli Belorussii trebuyut otstavki pravitel'stva (Business promises Lukashenko a big problem: entrepreneurs demand the government's resignation)." Nevazimaya gazeta. Accessed Jul. 2, 2017. http://www.ng.ru/cis/2016-02-29/1_lukashenko.html

Huntington, Samuel, and Clement Moore. 1970. "Conclusion: Authoritarianism, Democracy and One-party Politics.' In Authoritarian Politics in Modern Society: The Dynamics of Established Oneparty Systems. Edited by S. Huntington and C. Moore, 509-517. New York: Basic Books.

Interfax. 2014. "Ves' ob"'em eksportnykh poshlin ot prodannykh RB v 2015 godu nefteproduktov poidet v belorusskii byudzhet (All export duties on the sale of Belarus oil products in 2015 to go to the Belarus budget).” Accessed Jul. 2, 2017. http://www.interfax.by/news/belarus/1168549

Jackson, R. 2013. "Regime Security.” In Contemporary Security Studies, edited by A. Collins, 161175. Oxford, UK: Oxford University Press.

Kobrinskaya, Irina. 2007. "The Post-Soviet Space: From the USSR to the Commonwealth of Independent States and Beyond." In The CIS, the EU and Russia, edited by K. Malfliet, L. Verpoest and E. Vinokurov, 13-21. Hampshire: PalgraveMacmillan.

Keohane, R. 2005. After hegemony: Cooperation and discord in the world political economy. Princeton: Princeton University Press.

KISI. 2014. Vospriyatie grazhdanami voprosov evraziiskoi integratsii i uchastiya kazakhstana v evraziiskom soyuze (Citizen perceptions toward the question of Eurasian integration and the participation of Kazakhstan in the EAEU). Kazakhstanskii institut strategicheskikh issledovanii pri Prezidente Respubliki Kazahstana (The Kazakhstan Institute for Strategic Research under the President of the Republic of Kazakhstan) : Astana.

Kopstein, Jeffrey, and David Reilly. 2000. "Geographic Diffusion and the Transformation of the Postcommunist World.” World Politics 53: 1-37.

Kremlin. 2015. Vstrecha s Prezidentom Belorussii Aleksandrom Lukashenko (Meeting with the Belarus President Aleksandr Lukashenko). Accessed Jul. 2, 2017.

http://kremlin.ru/events/president/news/49888

Lane, David. 2015. "Introduction: Eurasian Integration as a Response to Neo-Liberal Globalization." In The Eurasian Project and Europe, edited by D. Lane and V. Samokhvalov, 3-22 New York: Palgrave Macmillan.

Libman, Aleksandr. 2015. "Supranational Organizations: Russian and the Eurasian Economic Union.” In Autocratic and Democratic External Influences in post-Soviet Eurasia, edited by A. Obydenkova and A. Libman, 133-158. Ashgate, UK: Farnham. 
Libman, Aleksandr, and Evgeny Vinokurov. 2012. Holding-together Regionalism: Twenty Years of Post-Soviet Integration. Hampshire, UK: Palgrave Macmillan.

Likhachev, Maksim. 2015. "Obraz EAES v mediaprostranstve Kazakhstana, Rossiiskii institut strategicheskikh issledovanii (The EAEU in the Kazakhstani media).” Accessed Jul. 2, 2017. https://riss.ru/analitycs/22235/

Lipman, Maria. 2015. "Putin's enemy within: Demonising the 'fifth column'." European Council on Foreign Relations. Accessed Jul. 2, 2017.

http://www.ecfr.eu/article/commentary_putins_enemy_within_demonising_the_fifth_column31151 3

Lukashenko, Aleksandr. 2012. "Lukashenko i Putin dogovorilis' sovmestno borot'sya protiv sanktsii Zapada (Lukashenko and Putin agreed on a join fight against Western sanctions)." Accessed Jul. 2, 2017. http://telegraf.by/2012/06/lukashenko-i-putin-dogovorilis-sovmestnoborotsya-protiv-sankcii-zapada

Lukashenko, Aleksandr. 2016. "Doklad Prezidenta Belarusi na pyatom Vsebelorusskom narodnom sobranii (Report of the president)." Accessed Jul. 2, 2017.

http://president.gov.by/ru/news_ru/view/uchastie-v-pjatom-vsebelorusskom-narodnom-sobranii$13867 /$

Marples, David. 2016. “What Is At Stake in the Small Traders Protests?” Belarus Digest. Accessed Jul. 2, 2017. http://belarusdigest.com/story/what-stake-small-traders-protests-24292

Mattli, Walter. 1999. The Logic of Regional Integration. New York: Cambridge University Press.

Mgov.Kz. 2016. "Kazakhstan vvel vremennye ogranicheniya na postavku krupno-rogatogo skota iz Rossiiskoi Federatsii (Kazakhstan introduced temporary restrictions on the supply of cattle to Russia). ” Accessed Jul. 2, 2017. http://mgov.kz/ru/aza-stan-respublikasy-resej-federatsiyasynan-iriara-mal-kirgizuine-ua-ytsha-shekteuler-engizdi/

Miller, Eric. 2006. To Balance or not to Balance: Alignment Theory and the Commonwealth of Independent States. Aldershot, UK: Ashgate.

Miller, Eric, and Arkady Toritsyn. 2005. "Bringing the Leader back in: Internal Threats and Alignment Theory in the Commonwealth of Independent States." Security Studies 14: 325-363.

Milner, Helen. 1997. Interests, Institutions and Information. New Jersey: Princeton University Press.

Moravcsik, Andrew. 1997. "Taking Preferences Seriously: A Liberal Theory of International Politics.” International Organization 51: 513-553.

Moravcsik, Andrew. 1998. The Choice for Europe. Ithaca, NY: Cornell University Press.

Moscow Times. 2014. "Belarus' Lukashenko: Russia's Behaviour Arouses Suspicion.” Accessed Jul. 2, 2017. http://www.themoscowtimes.com/news/article/belarus-lukashenko-says-russia-sbehavior-arouses-suspicion/513476.html 
Neumann, Iver. 2003. “A Region-building Approach.” In Theories of New Regionalism, edited by F. Soderbaum and T. Shaw, 160-178. New York: Palgrave Macmillan.

Nye, Joseph. 1968. “Central American Regional Integration.” In International Regionalism: Readings edited by J. Nye, 377-427. Boston, MA: Little, Brown and Company.

Obydenkova, Anastassia, and Aleksandr Libman. 2015. "Modern External Influences and the Multilevel Regime Transition: Theory Building." In Autocratic and Democratic External Influences in post-Soviet Eurasia, edited by A. Obydenkova and A. Libman, 7-47. Ashgate, UK: Farnham.

Olcott, Martha, Anders Åslund, and Sherman Garnett. 1999. Getting It Wrong: Regional Cooperation and the Commonwealth of Independent States, Washington, DC: The Brookings Institution Press.

Keukeleire, Stephan and Irina Petrova. 2016. 'The European Union, The Eastern Neighbourhood and Russia: Competing regionalisms'. In M. Telo (ed), European Union and New Regionalism, 263-279. New York: Routledge.

Pevehouse, Jon. 2002. "Democracy from the Outside-In?-International Organizations and Democratization.” International Organization 56: 515-549.

Priess, David. 1996. "Balance-of-threat Theory and the Genesis of the Gulf Cooperation Council." Security Studies 5: 143-171.

Putin, Vladimir. 2011. "Novyi integratsionnyi proekt dlya Evrazii - budyshchee, kotoroe rozhdaetsya segodnya (A New Integration Project for Eurasia-The Future Which is Being Conceived Today)." Izvestiya, October 3. Accessed Jul. 2, 2017. http://izvestia.ru/news/502761

Putin, Vladimir. 2014a. "Soveshchanie s chlenami pravitel'stva. 12 fevralya 2014 goda, Moskovskaya oblast', Novo-Ogarevo (Meeting with members of the government)." Kremlin.ru. Accessed Jul. 2, 2017. http://special.kremlin.ru/events/president/news/20217

Putin, Vladimir. 2014b. "Obrashchenie Prezidenta Rossiiskoi Federatsii (Address of the President to the Russian Federation).” Kremlin.ru. Accessed Dec. 2, 2017

http://www.kremlin.ru/transcripts/20603

Putnam, Robert. 1988. "Diplomacy and Domestic Politics: The Logic of Two-Level Games." International Organization 42: 427-460.

RIA Novosti. 2016. "V Kazakhstane prodlili moratorii na popravki v Zemel'nyi kodeks (The moratorium on changes to the land code continue in Kazakhstan)." Accessed Jul. 2, 2017. https://ria.ru/world/20160819/1474754617.html

Roberts, Sean, and Arkady Moshes. 2016. "The Eurasian Economic Union: A Case of Reproductive Integration?” Post-Soviet Affairs. 32: 542-565.

Rodeheffer, Luke. 2015. "Is a Trade War brewing between Russia and Kazakhstan? Global Risks Insights.” Accessed Jul. 2, 2017. http://globalriskinsights.com/2015/06/is-a-trade-war-brewingbetween-russia-and-kazakhstan/ 
Rosset, Damian, and David Svarin. 2014. "The Constraints of the Past and the Failure of Central Asian Regionalism, 1991-2004." Region: Regional Studies of Russia, Eastern Europe, and Central Asia 3: 245-266.

Savchenko, I. 2015. "Kazakhstan rejects statements of the UN, EU and OSCE on violations of human rights." Open Dialogue. Accessed Jul. 2, 2017. http://en.odfoundation.eu/a/7073,kazakhstanrejects-statements-of-the-un-eu-and-osce-on-violations-of-human-rights

Schimmelfennig, Frank, and Ulrich Sedelmeier. 2005. "Introduction: Conceptualizing the Europeanization of Central and Eastern Europe." In The Europeanization of Central and Eastern Europe, edited by F. Schimmelfennig and U. Sedelmeier, 1-28. Ithaca, NY: Cornell University Press.

Silitski, Vitali. 2010. "Survival of the Fittest: Domestic and International Dimensions of the Authoritarian Reaction in the former Soviet Union following the Colored Revolutions." Communist and Post-Communist Studies 43: 339-350.

Soderbaum, Frank, and Thomas Shaw. 2003 Theories of New Regionalism. New York: Palgrave Macmillan.

Solov'eva, Olga. 2016. "Moskva i Astana podelili krizis: Za poslednie dva goda jekonomiki Rossii i Kazakhstana sokratilis' v dollarovom izmerenii vdvoe (Moscow and Astana share a crisis)." Accessed Jul. 2, 2017. http://www.ng.ru/economics/2016-05-31/4_astana.html

Tansey, Oisn. 2016. The International Politics of Authoritarian Rule. Oxford, UK: Oxford University Press.

Ter-Matevosyan, V., Drnoian, A., Mkrtchyan, N., and Yepremyan, T. 2017. 'Armenia in the Eurasian Economic Union: reasons for joining and its consequences'. Eurasian Geography and Economics, 58: 340-360.

Ulfelder, Jay. 2008. "International Integration and Democratization: An Event History Analysis." Democratization 15: 272-296.

van der Vleuten, Anna, and Andrea Hoffmann. 2010. "Explaining the Enforcement of Democracy by Regional Organizations: Comparing EU, Mercosur, and SADC." Journal of Common Market Studies 48: 737-758.

Vinokurov, Evgeni. 2007. "Russian approaches to integration in the post-Soviet space in the 2000s." In The CIS, the EU and Russia, edited by K. Malfliet L. Verpoest and E. Vinokurov. Hampshire, UK: Palgrave Macmillan.

Vinokurov, Evgeni and Aleksandr Libman. 2012. Eurasian Integration: Challenges of Transcontinental Regionalism. Hampshire: PalgraveMacmillan.

Vinokurov, Evgeni. 2017. "Eurasian Economic Union: Current State and Preliminary Results." Russian Journal of Economics 3: 54-70. 
Von Soest, Christian. 2015. "Democracy Prevention: The International Collaboration of Authoritarian Regimes.” European Journal of Political Research 54: 623-638.

Walt, Stephen. 1987. The Origins of Alliances. Cornell University Press: New York.

Waltz, Kenneth. 2010. Theory of International Politics. Illinois: Waveland Press.

White, Stephen, and Valentina Feklyunina. 2014. Identities and Foreign Policies in Russia, Ukraine and Belarus. New York: Palgrave Macmillan.

Whitehead, Laurence. 2014. "Anti-democracy Promotion: Four Strategies in search of a Framework." Taiwan Journal of Democracy 10: 1-24.

Wolczuk, K., and Dragneva, R. 2017. 'The Eurasian Economic Union: Deals, Rules and the Exercise of Power'. Chatham House Research Paper, Accessed November 2, 2017. https://www.chathamhouse.org/publication/eurasian-economic-union-deals-rules-and-exercisepower

World Bank. 2017a. EU. Accessed Jul. 2, 2017. http://data.worldbank.org/region/european-union World Bank. 2017b. China. Accessed Jul. 2, 2017. http://data.worldbank.org/country/china Zlotnikov, L. 2004. "In the Noose of Populism: Eleven Years of the Belarusian Economic Model (1991-2001)." In The EU and Belarus: Between Moscow and Brussels, edited by A. Lewis, 127155. London: The Federal Trust for Education and Research.

\section{Appendix 1. Interviews (alphabetical)}

Akberdin, Rustam. Director of the Department for Development Entrepreneurship, Eurasian Economic Commission, (headquarters in Moscow).

Amrebayev, Aidar. Head of the First Kazakhstani President Centre, Institute of World Economics and Politics (IWEP), Kazakhstan.

Askarov, Tulegen. President of the Centre for Business Journalism BizMedia, Kazakhstan.

Bakenov, Ernar. Director of the Department of International Economic Integration, Kazakhstan.

Brodov, Roman. Head of Foreign Economic Policy Division, Ministry for the Economy, Belarus.

Busko, Vitaly. Member of the House of Representatives, Deputy Chairman of the Standing Commission on International Affairs, Belarus.

Evseev, Vladimir. Deputy Director, The CIS Institute, Russia.

Filippov, Alexander. Head of the Youth Affairs Department, Belarusian State University of Culture and Arts; previously expert with the Information-Analytical Centre of the Administration of the President (2010-2013), Belarus. 
Guryanov, Alexander. Deputy-Minister for Foreign Affairs, Belarus.

Kariagin, Vladimir. Chairman of Belarusian Republican Confederation of Entrepreneurship, Belarus.

Karimsakov, Murat. President of the Eurasian Economic Club of Scientists, Kazakhstan.

Kassenova, Nargis. Director of Central Asian Studies, KIMEP University, Kazakhstan

Kishkembayev, Askar. Head of the Secretariat of the Minister for Economy and Financial Policy, Eurasian Economic Commission, (headquarters in Moscow).

Knobel, Aleksandr Laboratory of International Trade, Gaidar Institute for Economic Policy, Russia.

Kortunov, Andrei. President of the New Eurasia foundation, Russia.

Kozhakov, Asan. Ambassador-at-Large, Ministry of Foreign Affairs, Kazakhstan.

Kravchenko, Valentina. Deputy Director of the Department for Financial Policy, Eurasian Economic Commission, (headquarters in Moscow).

Krishtapovich, Lev. Deputy Director of the Information-Analytical Centre of the Administration of the President, Belarus.

Mukhamedjanova, Darya. Chief Research Fellow, Economic Studies Department, Institute for Strategic Studies, Kazakhstan.

Nursha, Askar. Coordinator of Projects on Foreign Policy Issues, Institute of World Economics and Politics (IWEP), Kazakhstan.

Polyanski, Dmitry. Deputy Director, First Department of CIS countries, Ministry for Foreign Affairs, Russia.

Postnikova, Natalya. Senior Research Fellow, Gaidar Institute for Economic Policy, Russia.

Rakhmatullina, Gulnar. Minister for Economic and Financial Policy, Eurasian Economic Commission, (headquarters in Moscow).

Rusakovich, Andrei. Head of the Foreign and Security Policy Studies Centre, Belarus.

Sankubayev, Amirbek. Head of the Financial Market Division, Eurasian Economic Commission, (headquarters in Moscow).

Satpayev, Dosym. Director of the Risk Assessment Group, Kazakhstan.

Sultangalieva, Alma. Advisor to the Director, Institute of World Economics and Politics (IWEP), Kazakhstan.

Survillo, Vitali. Vice President of All-Russia Public Organization Delovaya Rossiya, Russia.

Ulakhovich, Vladimir. Deputy Chair of the Chamber of Trade and Commerce, Belarus. 
Volchkova, Natalya. Lead Economist, Centre for Economic and Financial Research, Russia. 